\title{
Why do students categorize teachers differently in Tanzanian secondary schools?
}

\author{
Komba, Sotco Claudius $\bowtie$ \\ Sokoine University of Agriculture, Tanzania (sotratz@sua.ac.tz) \\ Kanani, Advodia Joseph \\ President's Office, Regional Administration and Local Government, Tanzania (advodiakanani5@gmail.com)
}

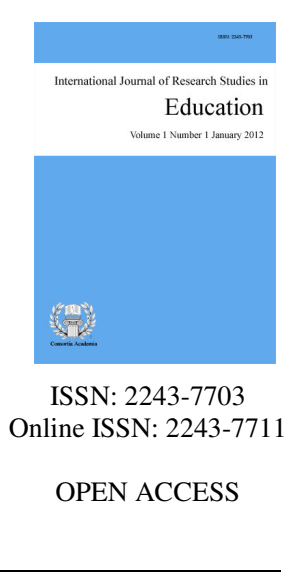

Received: 3 January 2020 DOI: $10.5861 /$ ijrse.2020.5004

Accepted: 4 April 2020

\begin{abstract}
The overall objective of this study was to investigate reasons for different categorization of teachers by secondary school students in Tanzania. The specific objectives included to determine reasons for different categorization of teachers by students in the selected schools; to examine whether the categorization of teachers by students differed across schools; to examine whether the categorization of teachers by students affected students' academic performance; and to recommend the best ways for enhancing relationship between teachers and students in secondary schools. The study was conducted in Iringa and Morogoro Regions, involving 80 students from five secondary schools. Data collection was done through focus group discussions whereas content analysis was used to analyze the collected data. The findings were as follows: First, personal, pedagogical and professional characteristics constituted most of the reasons which made students to categorize their teachers differently. Secondly, students had the same reasons for categorizing teachers differently irrespective of the location of their schools. Third, the categorization of teachers as either good or bad affected students' academic performance differently as students performed better in subjects taught by teachers categorized as good than the subjects taught by bad teachers. Lastly, it was recommended that both teachers and students ought to play their roles responsibly in order to enhance relationship between the two parties. In view of this, the Tanzania Institute of Education, in collaboration with teacher education institutions, should regularly review teacher education curricula to ensure that student teachers become knowledgeable, skilled, competent, and morally upright.
\end{abstract}

Keywords: qualitative study; Tanzania; teacher education; categorization; effective teacher 


\section{Why do students categorize teachers differently in Tanzanian secondary schools?}

\section{Introduction}

Secondary school education is the level of education attained by students after going through primary education under criteria set by the country. In Tanzania, students join secondary education after passing the Primary School Leaving Examination (PSLE), administered at the end of seven years of schooling. The primary school leaving examination aims at assessing learners' skills and knowledge gained in different subjects prior to joining secondary school. In Tanzania, secondary education has two levels: ordinary secondary education level (Form 1-4) which is attained after completing primary level and advanced secondary education level (Form 5-6) which is also attained after passing the Certificate of Secondary Education Examination (CSEE), administered at the end of four years of ordinary secondary education. After completing the advanced secondary education level, students can either join tertiary institutions or universities to pursue higher education. The education system in Tanzania is controlled by the Ministry of Education, Science and Technology, which is responsible for making policies and guidelines, and the President's Office - Regional Administration and Local Government, which deals with all matters related to the management of schools.

In order to achieve equity, equality, and quality in the provision of education, the Ministry of Education, Science, and Technology, in collaboration with the President's Office - Regional Administration and Local Government, have to ensure that teachers are available in schools. To that effect, teachers are posted in different schools to facilitate the process of teaching and learning, with a view of enabling students to acquire skills and competences as implied in the school curricula.

In the course of teaching and learning, both teachers and students have roles which have to be accomplished within the school context. It has been revealed that when teachers execute their roles, students tend to develop different perceptions which result in categorizing the teachers differently (Rhalp, 2003; Strikwerda-Brown, Oliver, Hodgoson, Palmer, \& Watts, 2008; Lee, Sattayawaksakul, Waleesila, \& Sriharat, 2009; URT, 2008; Fuhrman, 2014). In Tanzanian secondary schools, most students perceive their teachers differently as some of them are categorized as good teachers while others are viewed as bad teachers. Studies have indicated that students have different reasons for categorizing their teachers (Worthington, 2002; Suplicz, 2009;Rhalp, 2003; Matsumoto, 2010; Jerome, 2003; Bullock, 2015; Lee et al., 2009; URT, 2008; Fuhrman, 2014). In addition, it has also become evident that the categorization of teachers by students has impact on students' academic performance (Scarboro, 2012).

Reasons for the categorization of teachers by students differ across countries as it will be delineated in the subsequent section. It was, thus, worth conducting this study to examine the phenomenon in the context of Tanzanian secondary schools, with a view of establishing its existence, nature, and trends. Specifically, the study sought to determine reasons for different categorization of teachers by secondary school students; examine whether the categorization of teachers by students differ across schools; examine whether the categorization of teachers by students affect students' academic performance; and recommend the best ways for enhancing relationship between teachers and students in secondary schools.

It was envisaged that the study findings would enable researchers to recommend appropriate ways for enhancing relationship between teachers and students in secondary schools for better academic performance and quality education provision.

\section{Literature review}

A teacher is defined differently by different scholars. For example, Nyerere (1966), as cited by Zombwe (2007), defines a teacher as the only person who is capable of imparting knowledge and shaping the youths to 
the wider scope of knowledge. On the other hand, Senge (2000) defines a teacher as the expert who is capable of imparting knowledge that will help learners to build, identify, and acquire skills that will be used to face the challenges in real life situations. Moreover, a teacher could also be viewed as a person who is capable of creating behavioral change in terms of cognitive, psychomotor as well as affective domain (Mbise, 2008). Deducing from these definitions, a teacher could generally be viewed as a person who uses their professional skills to enable learners acquire desirable knowledge and skills which are applicable in real life situations.

The concepts of good and bad teachers, which are the hinge point of this paper, are difficult to be explained in a single term. The two categories of teachers are explained differently by different scholars depending on what constitutes each category. For instance, Biggs (1999), views a good teacher as the one who makes efforts to help learners to learn. Thus, a good teacher is viewed as the one with positive views regarding teaching and who desires to help students to discover their potential and become independent. In the same light, Phillips (1990) argues that a good teacher is the one who links the theoretical assumptions presented in books with the surroundings so that learners can use them to satisfy the societal expectations.

On the other hand, a bad teacher, therefore, can be perceived as the one whose characters are the opposite of a good teacher. For example, Rainer (2015) views a bad teacher as the one who is lazy, disorganized, disconnected, and poor in communication. These are essentially teachers who are ineffective in assisting learners to attain their learning outcomes.

It is worth noting that within a school setting, teachers and students work together to have the learning outcomes, as specified in the school curricula, realized. The learning outcomes have to be achieved through different roles played by both teachers and students in the school context. Teachers, in particular, play different roles which include teaching, assessing, guiding, supervising, managing, and making judgements about their students. On the other hand, students play roles such as learning, imitating good and bad things, making judgements about themselves and their teachers, observing different things, and participating in extra curricula activities, including sports and games, gardening, and cleanliness. When the two parties (teachers and students) play their respective roles through interactions with each other, students develop some attitudes which, often, result in misunderstandings or even conflicts with their teachers. Due to the misunderstandings between the two parties, students may categorize their teachers as either good or bad depending on different perceptions.

A good number of studies have been conducted worldwide on the categorization of teachers as perceived by students. For example, Strikwerda - Brown et al., (2008) conducted a study on how rural adolescent secondary school students viewed their teachers. The findings showed that students perceived teachers in two ways: good and poor teachers. Their views reflected different dimensions such as teachers' expertise, pedagogical approaches, and emotional environments. In the same light, Lee et al., (2009) examined students' perceptions about their college teachers. The findings indicated that knowledge in the subject matter was an important quality which made college teachers or university lecturers be perceived as either good or poor. Moreover, Fuhrman (2014) conducted a study to determine students' perceptions on their teachers. The findings revealed that students perceived good teachers as those who can explain things in an understandable manner and enhance the clarity of explaining by giving practical-oriented examples. Also, Jerome (2003) conducted a study to solicit views from high school students on what they considered to be the most important characteristics of an effective teacher. In this study, students indicated the top five characteristics of an effective teacher as being knowledgeable, humorous, respectful, patient and organized. In some ways, Jerome's study is in line with the study conducted by Bullock (2015) who found that characters related to technological skills, content knowledge, and pedagogical skills were important in determining the quality of a good.

Furthermore, Matsumoto (2010) conducted a study on university students' perceptions and altitudes about their teachers' talk in Japanese second language classroom sessions. The study focused on various aspects including the rate of speech, use of visual and extra linguistic information and use of English instead of Japanese in the classroom. The findings revealed that the majority of students preferred teachers with natural speed in 
their speech and who used appropriate amount of new vocabularies and visual and extra linguistic information to make the concepts more clear. However, this study is different from the current study in a sense that it focused on the characteristics of teachers in the context of second language teaching and learning. In the current study, the researchers dwelt on general characteristics of good and bad teachers in the context of execution of roles by teachers in Tanzanian secondary schools.

Regarding the characteristics of bad teachers, Suplicz (2009) found that lack of pedagogical merits and the various related pedagogical flaws, poor knowledge on subject matter, and poor emotional acceptance were the main characteristics of a bad teacher. Related to the same were laziness, disorganization, un-approachability, and anxiousness.

In view of the cited studies, it is evident that the categorization of teachers as good and bad exist globally. The findings from different studies have revealed that students' perceptions which result in the categorization of teachers differ across places. For example, while in some countries, interest and knowledge about subject matter can be a reason for categorizing teachers as either good or bad, in other places class management skills and teachers' level of commitment to learners were regarded as main factors for such categorization. It is also worth noting that most of these studies were conducted outside Tanzania, hence the rationale for having this study conducted in Tanzanian context.

\section{Methodology}

This study employed a qualitative research approach, using a case study design, in obtaining required information needed to address the objectives of the study. The adoption of this approach was based on the reason that it allows a researcher to deal with subjective assessment of attitudes, opinions, and behavior (Kothari, 2004). The qualitative research approach was particularly relevant for this study as the researchers were interested to find out reasons that prompt secondary school students to categorize their teachers differently. On the other hand, a case study design was used since it allows in-depth investigations of a single person, group, event or community. Also, it permits the collection of detailed descriptive data which are usually qualitative in nature, using a variety of procedures. Given that the researchers sought to generate rich information on reasons for different categorization of teachers by students in secondary schools, a case study design was deemed appropriate.

The study was conducted in Morogoro and Iringa regions, specifically in Morogoro Municipality and Iringa Rural District, targeting all secondary school students. The sample for this study included secondary school students from some selected secondary schools in Morogoro Municipality and Iringa Rural District. A simple random sampling technique was used to select two secondary schools in Morogoro Municipality and three schools in Iringa Rural District, to make a total of five secondary schools which were involved in the study. From the five schools, form three and form four students were purposively selected to be involved in the study. The two classes of students were selected for the reason that students had been in the respective schools for a considerable period of time (i.e. three or four years). In view of this, they were better placed to provide reliable information on how they perceived their teachers, hence categorizing them differently.

In each school, students were stratified according to their class levels (i.e. form three and form four) and sex (i.e. male and female). By using a simple random sampling, a total of eight (8) students were selected from each class (i.e. four female and four male students), making a total of 16 students per each school (i.e. eight form three students plus eight form four students). This procedure was done across all schools involved in the study and the sum of students from all schools was, therefore, 80 students.

Data collection was mainly done through focus group discussions in which researchers interviewed students regarding the phenomenon under investigation. The discussion groups comprised eight students, each. During the discussion, both researchers and students were able to ask and answer questions, which resulted in the collection of rich information about reasons for different categorization of teachers by secondary school students. 
The study employed content data analysis technique, which involved arranging the collected data into themes, categories, and patterns. Then, the themes, categories, and patterns were subjected to a detailed analysis to determine consistency, frequency of occurrence, similarities and differences in relation to the objectives of the study. The analyzed data were finally presented in Tables and through respondents' voices.

\section{Findings and discussion}

\subsection{Reasons for different categorization of teachers by secondary school students}

The first objective of this study sought to determine reasons for different categorization of teachers by secondary school students. In order to achieve this objective, a total of 9 focus group discussions were held in selected secondary schools in Morogoro Municipality and Iringa Rural District. During the focus group discussions, it was revealed that students in the selected schools categorized teachers as either good or bad based on various reasons. With regard to good teachers, students who participated in the discussions provided various reasons for categorizing teachers as good, as summarized in Table 1.

\section{Table 1}

Reasons for categorizing teachers as good

\begin{tabular}{cl}
\hline S/N & \\
\hline 1 & Treating teaching profession as a vocation \\
2 & Using teaching style which enable students to understand their lessons \\
3 & Punishing only when it is necessary \\
4 & Having socially acceptable dressing style \\
5 & Being impartial \\
6 & Being a good listener \\
7 & Providing ample time for students to finish their assignments \\
8 & Being helpful \\
9 & Having a good mood \\
10 & Being humorous during teaching \\
11 & Being punctual \\
12 & Motivating students even when they underperform \\
13 & Being fair in examinations \\
14 & Not caning students during lessons \\
15 & Being friendly \\
16 & Using different teaching methods \\
17 & Being able to control emotions \\
18 & Not being boastful or arrogant \\
19 & Caring for students \\
20 & Having a good command of subject matter \\
\hline
\end{tabular}

As shown in Table 1, students who were involved in the focus group discussions, irrespective of their schools and location, provided various reasons for categorizing teachers as good. In the first place, it was revealed that teachers who were treating the teaching profession as vocation were more likely to be categorized by students as good teachers than their counterparts who were taking the teaching profession as other professions. Stressing on this attribute, one of the students from school D had this to state:

Some teachers do not consider their profession as vocation. They just take it like any other profession - which is wrong. Teachers have to exhibit certain characteristics which distinguish them from other people engaged in other professions. For example, teachers have to be good listeners, patient and resilient (FGD 5: D).

There were many other similar observations from other students in all schools which implied that teaching profession is unique in certain aspects such that if teachers have to be good, they have to abide by the uniqueness 
of this profession.

The other reason for categorizing teachers as good was linked to the teaching styles used by the teachers when delivering their lessons. On this aspect, students argued that a good teacher is the one who uses a variety of teaching methods which enable students to understand their lessons. It means that, if a teacher uses teaching methods which facilitate students' understanding of the subject matter delivered during lessons, such a teacher is likely to be categorized as a good teacher and the opposite is also true. One of the students from school A had this to report:

A good teacher ensures that during teaching, at least three quarters of the students understand the lesson. This can be achieved through teaching methods which provide opportunities for students to relate what goes on during the lessons with real life situations (FGD 3: A).

This excerpt shows that students do categorize their teachers based on their teaching styles, such that those who teach well are likely to be categorized as good teachers.

As shown in Table 1, there were many other reasons for categorizing teachers as good, including being impartial, humorous, friendly, helpful and having socially acceptable dressing styles, just to mention a few.

On the other hand, the researchers were also interested to find out reasons for categorizing teachers as bad, from students' perspective. During the focus group discussions, students admitted that there were teachers who were categorized by students as bad teachers and a good number of reasons were provided for categorizing their teachers in that manner. The reasons were as indicated in Table 2.

\section{Table 2}

Reasons for categorizing teachers as bad

\begin{tabular}{cl}
\hline S/N & \\
\hline 1 & Punishing students incautiously \\
2 & Having poor teaching styles \\
3 & Being unfair in examinations \\
4 & Using harsh language to students \\
5 & Threatening students during teaching \\
6 & Being unable to control emotions \\
7 & Being unfriendly \\
8 & Dressing improperly \\
9 & Being unable to motivate students \\
10 & Being uncooperative \\
11 & Misbehaving \\
12 & Being addictive to alcohol \\
13 & Not providing ample time for students to work on their assignments \\
14 & Caning students during lessons \\
15 & Not treating teaching profession as vocation \\
16 & Treating students unfairly \\
\hline
\end{tabular}

As indicated in Table 2, students provided 16 main reasons for categorizing teachers as bad. For example, students explained that some teachers punished students incautiously such that instead of assisting students to change their behavior, some punishments led to the development of hatred between the teachers and students. One of the students from school $\mathrm{C}$ had this to say:

We have teachers who seem to enjoy punishing students even when they are unsure whether the students have committed offences or not. I hate teachers who punish us without tangible reasons...these are the bad teachers we are talking about (FGD 6: C).

This shows that some teachers behave unprofessionally, which makes them be categorized as bad by their 
students.

In addition, it seemed that punishing students incautiously was a concern for many students in the visited schools. Some students reported that they felt bad when teachers punished them without sound reasons. It was also observed that some teachers spent most of their time walking around school compounds to find wrong doers and whenever one was caught misbehaving, they were caned. Thus, it seemed that teachers, who cane students frequently, are more likely to be categorized as bad teachers than their counterparts who provide alternative punishments. Moreover, teachers were also categorized by students as bad based on teaching styles employed during class sessions. On this aspect, students explained that some teachers used teaching styles which not only bored them but also made them inactive during the lessons. Stressing on this, one of the students from school E had this to report:

Some teachers use very boring teaching styles. For example, they do not allow students to ask questions during the lessons. We do not understand what they teach. That is why we categorize them as bad teachers (FGD1: E).

Thus, it seemed that some teachers were not using participatory teaching methods in their teaching, hence not only affecting students' interest in the subjects they taught, but also limiting students' better performance in the same.

Other reasons for categorizing teachers as bad, as reported by students, include being unfair in examinations, using harsh language to students, threatening students during teaching, being unfriendly, dressing improperly, being addictive to alcohol, not providing ample time for students to work on their assignments, treating students unequally, just to mention a few as shown in Table 2. Therefore, it could be deduced from these findings that teachers were categorized as bad because of reasons hinged on the aspects of irresponsibility, malpractice, and unprofessionalism.

In view of these findings, it could be concluded that personal, pedagogical, and professional characteristics constituted most of the reasons which made students categorize their teachers differently in the selected Tanzanian secondary schools. These findings agree with those of Pollari (2015) who found that a call to the profession, good teaching styles, good communication skills as well as personality factors, like being humorous and patient, defines a good teacher and the opposite reflects characteristics of a bad teacher. Likewise, Stronge (2007) revealed that professionalism and personality factors, like being a good listener, dressing appropriately, displaying a sense of humor as well as treating all students equally, were described to be characters of a good teacher while, believing that teaching is like any other job, expressing bias, and administering unpredictable punishments are characters of bad teachers. However, the findings of this study do slightly differ from those of Al-Mohaimeed and Khan (2014) who found that teachers' characters related to performance such as good communication skills, good organization of lectures and expertise on subject matter were perceived by students as important characters for a good teacher while personality characters like good sense of humor, good listening skills and proper dressing were less considered as qualities of an effective teacher. This implies that reasons for the categorization of teachers by students are accorded different weight by different students, depending on their perceptions and contexts.

\subsection{The extent to which the categorization of teachers by students differs across schools}

The second objective of this study sought to examine the extent to which the categorization of teachers differed across schools. It was assumed that since students are found in schools located in different places, including rural and urban settings, reasons for categorizing them would be different. As in the case of the first objective, focus group discussions, involving students, were held in all the selected schools. In the first place, the researchers were interested to find out whether the categorization of teachers by students existed in the selected schools. Secondly, the researchers were also interested to examine whether the reasons for categorizing teachers differed across the schools. 
The findings revealed that the categorization of teachers by students existed in all the selected schools where teachers were categorized as either good or bad. Moreover, it was found that reasons for categorizing teachers did not differ across schools. Teacher attributes related to personality, performance, and professional skills constituted most of the reasons for categorizing them as either good or bad in all the visited schools. For example, students from all the selected schools reported that teachers who used appropriate teaching styles were categorized as good while the opposite was also true. In the same light, teachers who were unfriendly, not caring, punishing students incautiously, or unable to control their emotions were categorized by their students as bad teachers in all the selected schools. Therefore, it seemed that the categorization of teachers by students followed the same pattern, irrespective of the location of school. The findings that there was no difference in categorizing teachers across schools could be attributed to the fact that teachers who teach in Tanzanian schools have homogeneous professional skills acquired from teacher training institutions found in the country. Because of similar professional backgrounds, it would be difficult to observe significant differences among them when performing their duties in schools.

It was interesting to note that reasons for categorizing teachers by students did not differ across schools. This is because all students involved in the focus group discussions reported personality, performance, and professional skills as the main reasons for categorizing teachers as either good or bad. These qualities are also reported by Pollari (2015), Stronge (2007), Suplicz (2009), Miller (1987), and Jerome (2003).

\subsection{Effects of categorizing teachers on students' academic performance}

Examining the effect of categorizing teachers as either good or bad on students' academic performance was the third objective sought to be achieved in this study. Based on some literature reviews, the researchers had the assumption that the categorization of teachers had implications on the students' academic performance, depending on how the teacher is categorized. Specifically, it was assumed that if a teacher is negatively categorized, their reaction may be negative as well, which could negatively affect students' academic performance. The opposite was also assumed to be true since the process of teaching and learning is essentially interactive and requires a health relationship between the parties involved in the process.

Through focus group discussions held in the selected schools, it was revealed that there were mixed responses about the extent to which the categorization of teachers affected students in their learning. First, some students felt that if teachers were categorized positively, their academic performance would be positive as well. In the same vein, it was also revealed that if teachers were categorized negatively, students' academic performance would, as well, be affected negatively. With regard to positive effects of categorizing teachers as good, the findings were as presented in Table 3.

\section{Table 3}

Effects of categorizing teachers as good

\begin{tabular}{cl}
\hline S/N & \\
\hline 1 & Students get motivated to study hard \\
2 & Teachers are motivated to work hard \\
3 & Psychosocial gap between students and teachers is reduced hence improved interactions \\
4 & Preference for subjects taught by good teacher is high among students \\
\hline
\end{tabular}

As indicated in Table 3, four main effects which affected students' performance positively were reported by students. First, students got motivated to study hard, hence enhancing their academic performance. Secondly, teachers felt comfortable and thus, worked hard to assist students in their studies, which also affected the performance of students in a positive manner. For example, students reported that good teachers motivated them to work hard and encouraged them not to despair even when the students underperformed. Stressing on this point, one of the students from school E had this to report: 
Good teachers love us and teach us well. They keep on encouraging us even when we do not do well in our subjects. Because of the continued motivation and encouragement, we ultimately perform better. I really love good teachers (FGD 8: E).

Therefore, it seemed that when teachers noted that they were categorized positively by their students, their morale increased, which consequently affected students' academic performance positively.

The other effect which was reported during the focus group discussions was that the psychosocial gap between teachers and students was reduced; a situation which enhanced interactions between the two parties. Such a situation affected students' academic performance in a positive manner. Lastly, it was revealed that if teachers were categorized as good, preference for subjects taught by such teachers was essentially high among students, hence putting more efforts to study such subjects and having their academic performance improved.

Moreover, the researchers were interested to find out whether the categorization of teachers as bad affected students' academic performance. During focus group discussions, it was surprisingly revealed that when teachers were categorized as bad, there were both positive and negative effects, as far as students' academic performance was concerned. The reported effects were as shown in Table 4 .

\section{Table 4}

Effects of categorizing teachers as bad

\begin{tabular}{cll}
\hline S/N & \multicolumn{1}{c}{ Positive effects } & \multicolumn{1}{c}{ Negative effects } \\
\hline 1 & Adoption of good teaching styles & Development of hatred \\
2 & Improved relationship with students & Development of psychosocial disorders \\
3 & Change of behavior for teachers & Lack of motivation for teachers \\
\hline
\end{tabular}

As shown in Table 4, students provided both positive and negative effects of categorizing teachers as bad. With regard to positive effects, students stated that when teachers were categorized as bad teachers, a good number of positive things which affected their academic performance positively were observed. First, the teachers adopted good teaching styles which enabled students to grasp contents of the lessons without difficulties. Secondly, there was an enhanced relationship between teachers and students, hence improved interactions which resulted in better academic performance. Lastly, there was an overall change of behavior among teachers who were categorized as bad, which affected their professional conduct positively, hence affecting positively students' academic performance.

With regard to negative effects of categorizing teachers as bad, students mentioned effects such as development of hatred between teachers and students, development of psychosocial disorders, and lack of motivation among teachers who were categorized as bad. All these affected negatively students' academic performance as the interactions between the two parties were limited because of perceptions held by each party. Therefore, from the students' perspectives, it could be deduced that the categorization of teachers as either good or bad affected students' academic performance differently. It seemed that students were better placed to perform well in subjects taught by teachers who were categorized as good compared to the subjects taught by bad teachers.

It is worth noting that students' academic performance is an outcome of many variables, including the relationships established among students themselves and between them and their teachers. Thus, it is envisaged that if positive relationships are established, students' performance is likely to improve. This is in line with the findings by Pianta (2004) who described positive teacher-student relationship as an essential element for better academic performance. In the same light, Little and Kobak (2003) found that students perform better when they have supportive relationship with their teachers. The better performance emanates from working harder in the classroom, accepting directions and criticism as well as paying more attention to the teachers. 


\subsection{Recommendations for enhancing teacher-student relationship}

The last objective sought to examine students' opinions on how best teacher-student relationship could be enhanced. Specifically, the researchers were interested to find out what teachers and students should do to ensure that the two parties have a healthy relationship. As it was the case with all other objectives, focus group discussions were held with students in the selected schools and recommendations given by students were as presented in Table 5.

\section{Table 5}

Recommendations for enhancing teacher-student relationship

\begin{tabular}{cll}
\hline S/N & \multicolumn{1}{c}{ Recommendations for teachers } & \multicolumn{1}{c}{ Recommendations for students } \\
\hline 1 & Treating students with humility & Being obedient to their teachers \\
2 & Administering punishments when necessary & Being cooperative to their teachers \\
3 & Treating teaching profession as vocation & Working hard \\
4 & Treating all students equally and fairly & Being punctual \\
5 & Being friendly to students & Obeying school rules \\
6 & Communicating with students using proper language & Behaving responsibly \\
\hline
\end{tabular}

As shown in Table 5, there were recommendations meant for teachers and others for students. With regard to recommendations for teachers, students reported that teachers have to treat students with humility and whenever there is a need to administer a punishment, it should be done cautiously and only when it is necessary. Moreover, students stated that teachers ought to treat the teaching profession as vocation, considering that it has unique features which make it differ significantly from all other professions. Other recommendations for enhancing teacher - student relationship included treating students equally and fairly, behaving friendly and communicating with students using proper language. Thus, it seemed that if teachers observe professionalism, there is a great likelihood for their relationship with students to be enhanced.

On the other hand, students reported that they had some obligations to fulfill in order to maintain harmonious relationship with their teachers. In particular, students stated that they were not only supposed to be obedient but also cooperative to their teachers. In addition, the students stated that they ought to be hard working, punctual, and responsible when they are within and outside school compounds. Also, it was recommended that students should abide by school rules in order to avoid unnecessary quarrels with teachers. When the given recommendations for teachers and students are carefully examined, it could be deduced that both teachers and students have to play their roles responsibly and abide by the professional code of conduct and stipulated rules, for the two parties to relate harmoniously. Teacher-student relationship is the way in which a teacher and student are connected while they are performing their roles within school settings. According to Pianta (1999), teacher-student relationship refers to the emotion-based experiences that emerge out of teachers' on-going interactions with their students. Enhancing teacher-students relationship is of great importance because students' achievements are linked to healthier relationships established with their teachers. This is supported by Wentzel (1998) who noted that students' motivation to learn is impacted positively by having a caring and supportive relationship with a teacher. The given recommendations concur with observations made by Boynton and Boynton (2005) who noted that communicating positive expectations to students, calling on all students' equitability, disciplining students in a corrective way and demonstrating caring are the ways of developing positive teacher- student relationship.

\section{Conclusion and recommendations}

The main objective of this study was to investigate reasons for different categorization of teachers by secondary school students. The findings have revealed that personal, pedagogical, and professional characteristics constituted most of the reasons which made students to categorize their teachers differently. This implies that, apart from profession-based reasons, individual characteristics make students to categorize their

56 Consortia Academia Publishing (A partner of Network of Professional Researchers and Educators) 
Attitude of engineering students towards engineering drawing: A case study

teachers differently. Based on these findings, it is recommended that the admission of student-teachers into teacher education institutions should be done in such a way that only applicants with a true call to become teachers are admitted to pursue teacher education programs. This could be done by asking the prospective teacher trainees to write motivation letters or subject the same to interviews to determine their levels of motivation for the teaching profession. In addition, the Tanzania Institute of Education, in collaboration with teacher education institutions, should regularly review teacher education curricula to ensure that student teachers are trained to become knowledgeable, skilled, competent and morally upright. If this is done, the teachers are likely to exhibit high levels of professionalism, hence minimizing the possibility of being categorized negatively by their students.

\section{References}

Al-Mohamaimeed, A. A., \& Khan, N. K. (2014). Perception of Saudi medical students on the qualities of effective teachers: A cross-sectional study. Saudi Medical Journal, 35(2), 183-188.

Brown, N. (2004). What makes a good educator'? The relevance of meta-programs. Assessment and Evaluation in Higher education, 29, 515-534. https://doi.org/10.1080/0260293042000197618

Bullock, M. (2015). What makes a good teacher? Exploring students and teacher beliefs on good teaching. Rising Tide, 7, 1-30.

Dalley-Trim, L. (2007). Students' observations and perceptions of teacher performances in the classroom. Australian Journal of Teacher Education, 32(1), 18-35. https://doi.org/10.14221/ajte.2007v32n1.2

Duarte, F P. (2013). Conceptions of good teaching by good teachers: Case Studies from an Australian University. Journal of University Teaching and Learning Practice, 10(1), 1-17.

Holloway, I., \& Wheeler, S. (2002). Qualitative research in nursing. Oxford: Blackwell Science.

Jerome, G..D. (2003). How high school students perceives effective teachers. Newfoundland: Memorial University Press.

Johnson, J. (2001). What makes a good teacher? University of Pittsburgh: University Press.

Kothari, C. R. (2004). Research methodology. New Delhi: New Age International.

Krueger, T. (1997). Oral communication skills necessary for successful teaching:The student perspectives. Educational Research Quarterly, 21(2), 13-26.

Little, M., \& Kobak, R. (2003) . Emotinal security with teachers and children's stress reactivity: A comparison of special-education and regular-education classroom. Journal of Clinical Child and Adolescent Psychology, 32, 127-138. https://doi.org/10.1207/S15374424JCCP3201_12

Marsh, H. W., \& Roche, L. A. (1997). Making students' evaluations of teaching effectiveness: The critical issues of validity, bias and utility. American Psychologist, 52(11), 1187-1197. https://doi.org/10.1037/0003-066X.52.11.1187

Matsumoto, H. (2010).Students' perceptions about teacher talk in Japanese-as-a-second-language classes. University of America. Arizona Working Papers in SLA and Teaching, 17, 53-74.

Mbise, A. S. (2008). Early childhood service delivery mapping and baseline study in Bagamoyo, Hai, Magu and Mtwara: Summary of findings and recommendations. Dar es Salaam: Ministry of Education and Vocational Training.

Miller, P. (2012). Ten characteristics of good teacher. English Teaching Forum, 25(1), 36-38.

Obidi, S. S. (1975). Towards the professionalization of teaching in Africa. West African Journal of Education, 9(2), 239-246.

Parahoo, K. (1997). Nursing research: Principles, process and issues. London: Macmillan. https://doi.org/10.1007/978-1-349-14559-1

Phillips, T. (1990). What is a good teacher? Cambridge: Cambridge University Press.

Pianta, R. C. (1999). Enhancing relationships between children and teachers. Washington, DC: American Psychological Association. https://doi.org/10.1037/10314-000

Polit, D. F., Beck, C. T., \& Hungler, B. P. (2001). Essential of nursing research: Methods, Appraisal and Utilization. Philadelphia: Lippincott.। 
Komba, S. C., \& Kanani, A. J.

Population National Bureau of Statistics. (2013). 2012 Population and housing census. Population distribution by administrative areas and ministry of finance office of chief government statistician president's office, finance, economy and development planning. Zanzibar: Dar es salaam.

Postman, N., \& Weingarten, C. (1969). Teaching as a subversive activity. New York: Delacorte Press.

Ralph, E. G. (1951). Effective college teaching: Fresh insights and exemplary practices. New York: Nova Science.

Rosenshine, B., \& Furst, N. (1971). Research on teacher performance criteria. In B. O. Smith (Ed.), Research in teacher education (pp. 37-72). Englewood cliffs, NS: Prentice-Hall.

Rudduck, J., Chaplain, R., \& Wallace, G. (1996). School improvement: What can pupils tell us? London: Fulton.

Scarboro, A. (2012).Students perception of good teacher. International Journals of New Trends in Arts, Sports and Science Education, 1(1), 49-66.

Senge, S. (2000). Schools that learn. New York: Double Day Publishing Group.

Stake, R. E. (1995). The art of case study research. Thousand Oaks, CA: Sage.

Strikwerda-Brown, J., Oliver, R., Hodgoson, D., Palmer, M., \& Watts, L. (2008). Good teachers/bad teachers: How rural adolescent students' views of teachers impact on their school experiences. Australian Journal of Teacher Education, 33(6), 29-43. https://doi.org/10.14221/ajte.2008v33n6.3

Stronge, J. H. (2007). Qualities of effective teachers. Association of supervision and curriculum development. Alexandria, VA: ASCD.

Suplicz, S. (2009). What makes a teacher bad? - Trait and learnt factors of teachers' competencies. Acta Polytechnica Hungarica, 6(3), 125-138.

Thomas, S. G. (2011). A typology of the case study in social science following a review of definition, discourse and structure. Qualitative Inquire, 17(6), 511-521. https://doi.org/10.1177/1077800411409884

Tiberius, R. G., \& Billson, J. (1991). The social context of teaching and learning. New Directions for Teaching and Learning, 45, 67-86. https://doi.org/10.1002/tl.37219914509

United Republic of Tanzania. (2008). Children perception of education and their role in society. Views of the Children 2007. Dar es salaam: Tanzania.

Wentzel, K. (1998). Social relationship and motivation in middle school: The role of parents, teachers and peers. Journal of education psychology, 90(2), 202-209. https://doi.org/10.1037/0022-0663.90.2.202

Worthington, A. (2002). The impact of student perceptions and characteristics on teaching evaluation: A case study in finance education. Assessment and Evaluation in Higher Education, 27(1), 49-64. https://doi.org/10.1080/02602930120105054

Zombwe, G. (2007). What is the role of education in the society? Tanzania: Hakielimu. 